\author{
UNIVERSIDADE DE SÃO PAULO \\ MUSEU DE ARQUEOLOGIA E ETNOLOGIA \\ PROGRAMA DE PÓS-GRADUAÇÃO EM ARQUEOLOGIA
}

\title{
Preservação óssea: um estudo tafonômico dos remanescentes ósseos humanos dos sambaquis fluviais do vale do Ribeira de Iguape, SP.
}

Rafael Bartolomucci

Dissertação de mestrado, apresentada ao programa de pós-graduação em Arqueologia, do Museu de Arqueologia e Etnologia da Universidade de São Paulo.

Linha de Pesquisa: Espaço e organização social

Orientadora: Prof ${ }^{\mathrm{a}}$. Dr ${ }^{\mathrm{a}}$. Márcia Angelina Alves 


\author{
UNIVERSIDADE DE SÃO PAULO \\ MUSEU DE ARQUEOLOGIA E ETNOLOGIA \\ PROGRAMA DE PÓS-GRADUAÇÃO EM ARQUEOLOGIA
}

\title{
Preservação óssea: um estudo tafonômico dos remanescentes ósseos humanos dos sambaquis fluviais do vale do Ribeira de Iguape, SP.
}

Dissertação de mestrado, apresentada ao programa de pós-graduação em Arqueologia, do Museu de Arqueologia e Etnologia da Universidade de São Paulo.

Rafael Bartolomucci ( $\mathrm{n}^{\circ}$ USP: 1902791)

Orientadora: $\operatorname{Prof}^{\mathrm{a}}$. $\mathrm{Dr}^{\mathrm{a}}$. Márcia Angelina Alves 


\section{Dedicatória}

Aos meus pais, Sergio e

Gracinda, e a Ligia pelo eterno carinho nesta jornada. 


\section{Agradecimentos}

Agradeço inicialmente a minha orientadora Profa. Dra. Márcia Angelina Alves, cuja orientação foi importantíssima para a conclusão deste trabalho.

Devo ressaltar que a realização deste trabalho foi possível graças a um árduo trabalho, mais coletivo do que propriamente individual. Agradeço deste os autores citados na bibliografia as conversas com os colegas e professores do LAB-IB e dos MAE-USP.

Agradeço também ao Prof. Dr. Levy Figuti e ao Dr. Sergio Francisco Monteiro da Silva pelo apoio com as sugestões e correções do trabalho inicial.

Agradeço também aos Prof. Dr. Walter Alves Neves e Dra. Sabine Eggers pelo aprendizado e oportunidades de estagiar no Instituto de Biociências da USP, respectivamente no LEEH (Laboratório de Estudos Evolutivos Humanos) e no LAB (Laboratório de Antropologia Biológica).

Agradeço a todos os colegas, funcionários e amigos do LEEH, LAB e MAE.

Agradeço a FAPESP pelo auxilio financeiro inicial para esta pesquisa. 


\section{Epigrafe}

"Embora tenha aprendido a olhar o chão, nunca deixei de levantar minha cabeça."

B.R. 